\title{
On the tectonic processes along the Hellenic Arc
}

\author{
A. G. Gillanopolizos
}

Received on September $28 t \mathrm{~h}, 1974$

Sumary. - On the grounds of existing groplepsical data one might be allowed to conclude that the origin of the stress field in the Ionian center (Cephalonia-Zante-Patras) at the northwestern margin of the Aegean microplate is rather shallow and in the southeastern center (Dodecanese-Crete) is surely under the crust.

In the area oceupied by the second center of higher earthquake activity the relief of the Moho-discontinuity is shallower and smoother in comparison to that derived from gravity and seismic data for the area of the northwestern center. Another difference derived from the fault-plane solutions is that the Ionian eenter is seated in a region of horizontal pressure: the second center in the southeastern Aegean sea belongs to a region of paramount horizontal tension.

In the western side of the Hellenic are the high sediment supply rate, combined with a thickening of the liath's ceust along the Ionian zone, is interpreted as evidence that aceretion has occurred there until recently or may still be occurring locally: plate consumption, if any, is rather low.

The existence, on the other hand, of two very deep subparallel trenches with little fill southeast of (crete (Pliny trench, Strabo trench), combined with a very high suberustal activity in the southeastern margin of the Aegean subplate, sugrest that the subduction rate at the northern boundary of the ifrican plate must be relatively high; no plate accretion is expected to oceur there.

Riassuxto. - Basandosi sui dati geofisici esistenti si potrebbe conchudere che l'origine del campo di "stress "nel centro ionieo (Cefalonia-ZantePatras) al limite nord-oceddentale della micropiattaforma dell'Egeo è piut1osto in superficie, e nel centro sud-orientale (Dodecaneso-Creta) è sicuramente sotto la crosta.

Nell'area oceupata dal seeondo centro di magreiore attivita sismica il rilievo della Molo è neno profondo e meno accident ato in confronto a quello ricavato dai dati gravimetrici esismici per l'area del centro nord-oceidentale. 
Vonaltra differenza - tratta dalle soluzioni del piano di faglia - è che il contro ionico è situato in una zona sottoposta a pressioni orizzontali, mentre il centro nel mare Eegeo sud-orientale fa parte di una zona di fortissime tensioni orizzontali.

Nolla parte occirlentale dell'areo ellenico laalta velorita di apporto di sedimenti insieme al un ispessimento della crosta terrestre lungo la zona ionica, viene interpretata come la prova che l'acerescimento si è verificato molto di recente o è ancom localmente in atto; l'erosione della piattaforma, se esiste, è piuttosto bassa.

D’altra parte, l'esistenza di lue spaceature subparallele molto profonde e con piccolo apporto di materiale a sud-est di Creta (spaceatura di Pliny, spaceatura di Strabo) associata ad un'attivita sub-crostale molto intensa al margine sul-orientale della piattaforma sotto l'Fgeo, fa pensare che la velocita di subduzione al limite settentrionale della piattaforma africana deve assere relativamente alta. Non ci si aspetta quindi che ivi avvenga un accrescimento della piattaforma stessa.

\section{TNTRODLCTION}

The complex tectonies in the eastern Mediterranean maly be thought of as having been disentangled to some extent by the postulate of a number of minor plates between Europe and Africa, each in motion with respect to all arljacent plates. In the context of the plate tectonies, the tectonic zones along the southern borderlands of Europe may have been ereated by impingement, collision and relative motion of the postulated plates. These zones are often terminated by transform faults or rifted margins $\left({ }^{3}\right)$.

A decent number of microplates have been alrearly irlentified in the Mediterranean region on the basis of the present-rlay seismicity at their margins. They are from west to east: the Messinian, the Arlriatic, the Ionian, the Negean, the Turkish and the Levantine subplates (Fig. 1). Le Pichon is of the opinion, that the Aclriatic subplate may exist or it may be a finger of the Afriean plate within the Eurasian plate (16).

In a section from the reep trench south of Crete to the voleanic island of Santorini, the Mellenic subrluction system rlisplays the three erlgeocean typical zones: trench, are-trench gap and arc with the Cretan ridge at the outer part of the arc-trench gap (23).

Although the present relative motion of Africa with respect to Europe is of a northward compression, the relative motion that is oceuring at the southern border of Europe is not simply compressional but varies due to the interaction of the intervening microplates. Thus, as Dewey and others pointed out, the relative plate motion in the eastern 
Mediterranean today is to a large extent determined not by AfricaFurope motions but by the north-sonth compressive motion that is occurring between the Ambian plate on the one hand and the Furopan plate on the other. Arabia is separating from Africa along the Real Sea and the Gulf of Aden rift system. The Arabian plate, although thrusting uncler the Van plate along the Zagros, is pushing the Van plate north and werlging the Turkish plate westward along the north Anatolian fault ( ${ }^{(3)}$.

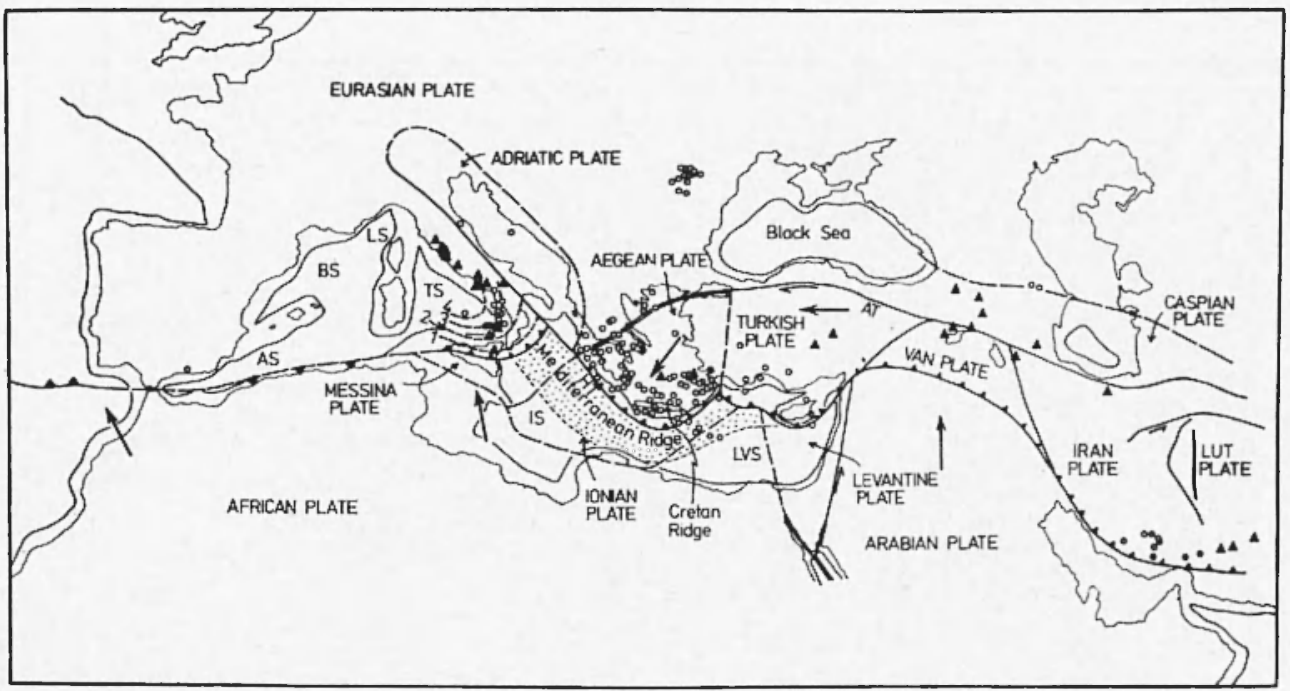

Fig. I - Neotectonies of the Aprine System; reproduced from Dewey and others, 1973 (Triangles = Quaternary and IJolocene Voleanoes; aircles = epicenters of earthoulies deeper than $100 \mathrm{~km}$; arrows $=-$ slip directions of plates with respecet to the Eurasian plate: dashed lines = contours on Benioff zone in hundresls of likometers).

The Aegean subplate, due to the westwarl squeezing of the Turkish subplate, moves apparently to the southwest with respect to Europe, the resulting differential motion between these plates and Africa being absorbed in the Hellenic trench south of Crete. This explains, according to Le Pichon and others, the moh higher seismic activity in the astern Merliteranean than in the western Mediterlanean (16). As pointed ont by McKenzie, the existence of the subsidiary plates may be thought of as minimizing the work to be done in the relative movement of shortening between Eurasia and If fica (- $)$. 


\section{SEISHotectonic MEATURES}

The Aegean subplate is bounded to the West and South by the Hellenic trough and two subparallel trenches, the pliny trench and the Strabo Trench, south of Crete. The north boundary of the plate runs along the postulated westerly prolongation of the north Anatolian shear fault zone; in the context of the prolongation, it was assumer that the north Anatolian dextral shear fault system continues through

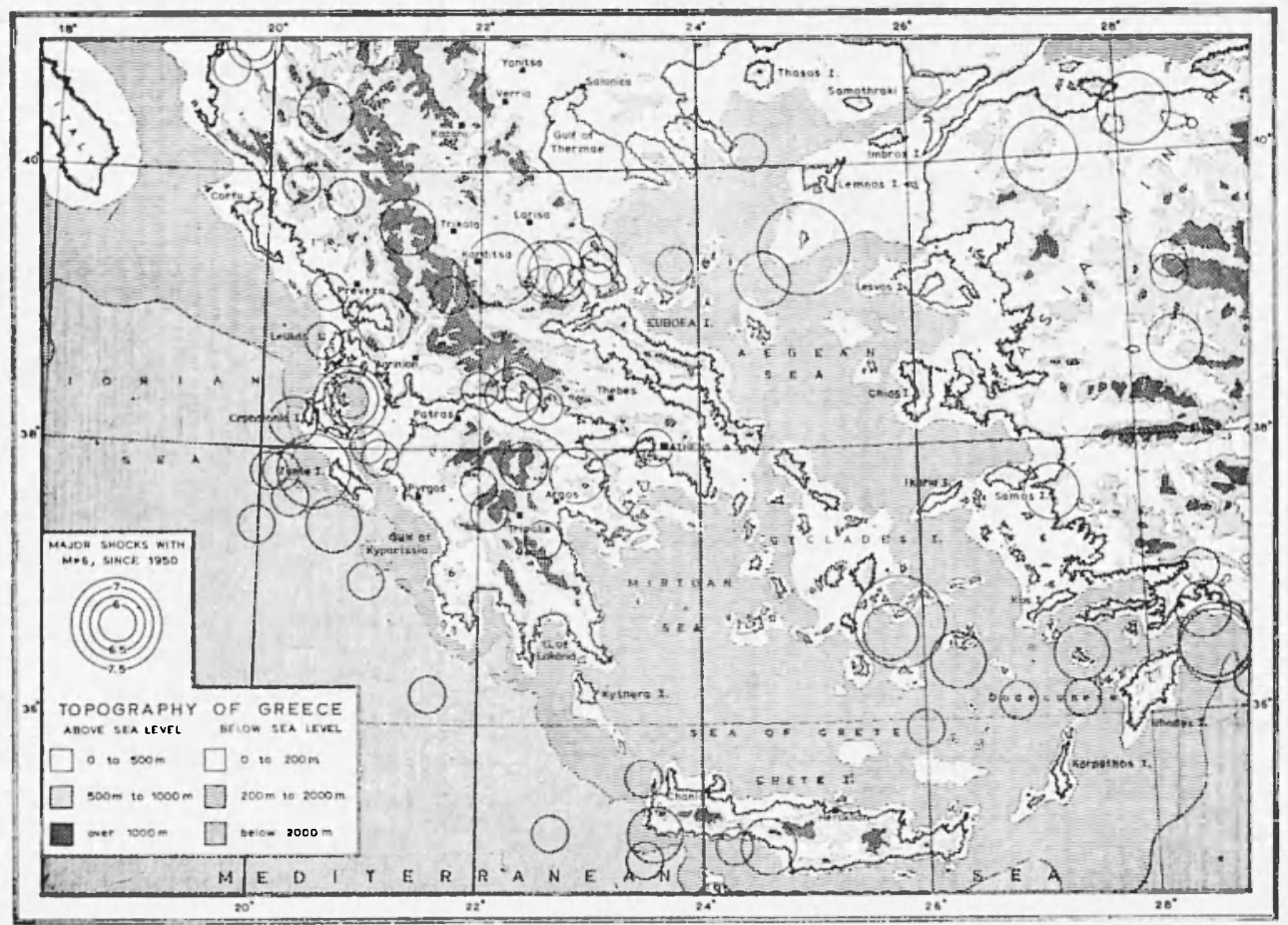

Fig. 2 - Map showing the distribution pattern of major shocks in relation to the topography of Girece.

the Trikkeri-Canal fanlt and some concealed, deep-seaterl transverse faults into the Gulf of Patras and the shear fault zone of CephaloniaZante $\left(^{6}\right)$. The lack of geological and morphological evirlence for transverse faults between the Trikkeri-Camal and the Gulf of Patras (Fig. 2), and the migration of the earthquake activity from Magnesia 
(Pharsala, Volos, Velestinon, 1954-195i) to the northern and northeastern Sporales (Alonisos, Skyros, St. Eustrate, 1965-1968), and in the same period to Eurytania and Acarnania (Kremasta, Katouna, 1966) and recently to the area of Leukas-Preveza (1973), favour the altemative that the Saros-Graben continnes in the Trikkeri-Iamia fault zone and

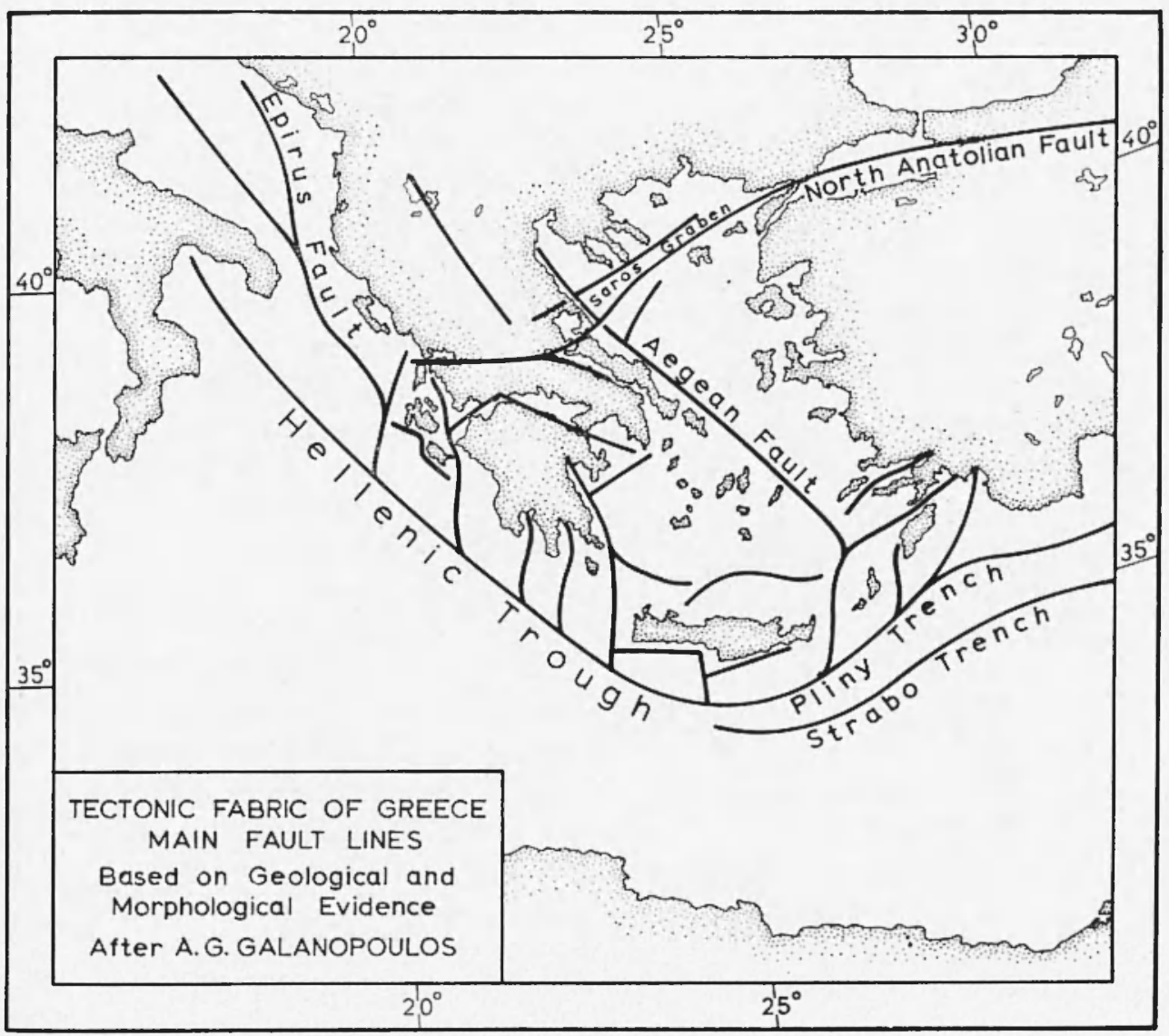

Fig. 3 - Simplified fanlt map of cereece.

through the northern fault escarpment of Oete mountain and the Quaternary Sperchios-Graben reaches the fault-bounded depression of the Ambrakikos Gulf (Fig. 3). The eastern boundary of the degean subplate is vaguely traced by a series of earthquake epicenters ruming from the Fethiye Gulf, between Rhorles and Kastellorizon, to the Gem- 
lik Gulf in the Marmara Sea. The recent seismic activity in Asia Minor, $1967-1970$, was seated apparently on the boundary of the Aegean and Turkish microplates (Fig. 4).

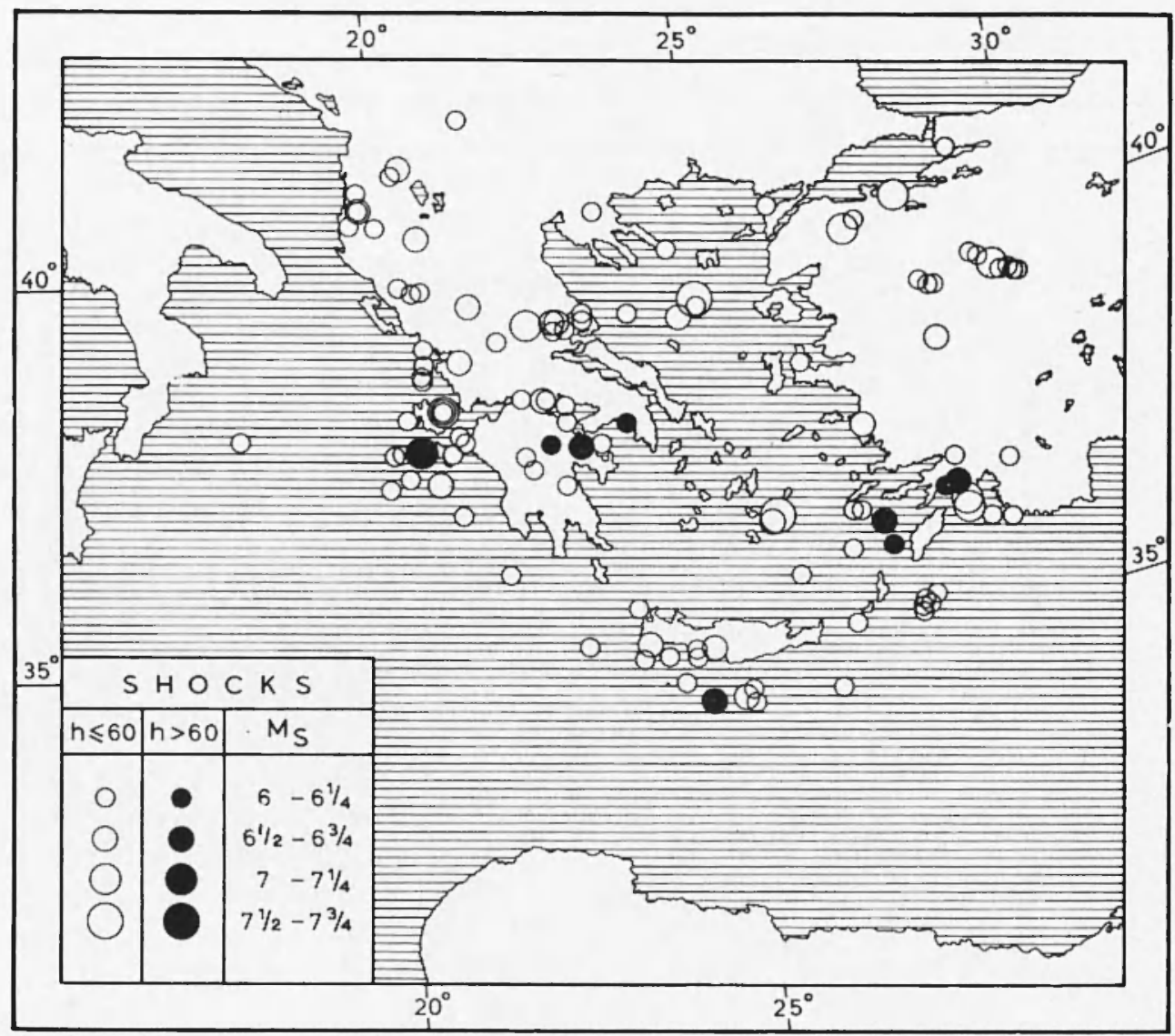

Fig. 4 - Farthquake epicenter map for the period 1950-1973.

The voleanic ane associated with the ITellenic subduction system starts from the voleanic islands of Nisyros-Yali-Kos, runs through the islands Santorini-Antiparos-Milos, it turns to the North and through Methana-Aegina-Isthmus reaches the group of the Quaternary volanoes St. Toannis, Likharles, Achilleion, Zileria, Thebes and Porphyrion, in the area of Tamia-Euboea-Magnesia (24). The voleanic are is in a roughly constant distance from the Hellenic Trough and the 
Trench system that surromnds the Aegean subplate. Between the voleanic are and the nearly parallel Itellenic Trongh runs the serlimentary are developed during the Cretaceons-Tertiary Alpine Orogeny (1). Among the Volcanoes of the IIellenic arc, Santorini, Nisyros and Methana were active in historical times; four volcanoes at the north end of the are, among which Likhades, were active in the IIolocene and probably till the end of the Neolithic age (12).

The epicenter map for the 120-years period, 1841-1960, for which the data on damaging and destructive shocks are complete $\left({ }^{5}\right)$, does not show any marker difference in the rlistribution pattern from the epicenter map for the 2t-years perior, $1950-1973$, for which the parameters of the earthquakes with $\mathrm{MI} \geqslant 5 \mathrm{1} / 2$ are known with much better aceuracy (lig. $\tilde{0})$.

In either of the epicenter maps, the boumlaries of the Aegean subplate are more or less clearly delineated by earthquake foci of continuous or sporalic activity. A common feature of the epicenter maps for Greece is the continuous and relatively higher earthqualie activity shown np at the northwestern and southenstern bounlaries of the Aegean microplate. The two diametrically opposed centers or "poles" with maximum activity in the area of Greece are marked by a strain energy release much higher than that appeared in any other sector of the degean subplate or in any sector of the other subsidiary plates which presumably exist in the Mediterranean (Fig. 1).

In a general scheme, the active seismic trend of Greece is approximately double $\Delta$-shaped, with the $\Delta$-sides perpendicular to each other, one of them being submeridian, and the perpendicular to it running subparallel, across the Hellenic Peninsula (Fig. 5).

The first attempt to give a good reason for the clustering of the majority of the epicenters around the two "poles", the nortliwestern and sontheastern margin of the legean microplate, has been strongly influenced by the relatively frequent and well documented observation of higher earthquake activity at the crosspoints of major fault zones, which generally yield to forces much easier. Biased from this principle, the concentration of the earthquake activity in the area of Cephalonia-zante-Patras has been firstly attributed to the intersection of the Ionian fault zone with the assumed prolongation of the north Inatolian sliear fault zone $\left({ }^{\circ}\right)$.

The second center of higher strain energy release in the area of Dodecanese-Crete is of predominanty suberustal origin; consequently, the existence of this center can not be easily explained in terms of 
the above principle. The area occupied by the second center and the energy radiated from it are much higher than in the first center $\left(^{\theta}\right)$.

The Tonian center (Cephalonia-Zante-Patras) at the northwestern margin of the Aegean subplate is a site of predominantly shallow, continuous earthquake activity associated with a pronounced low of

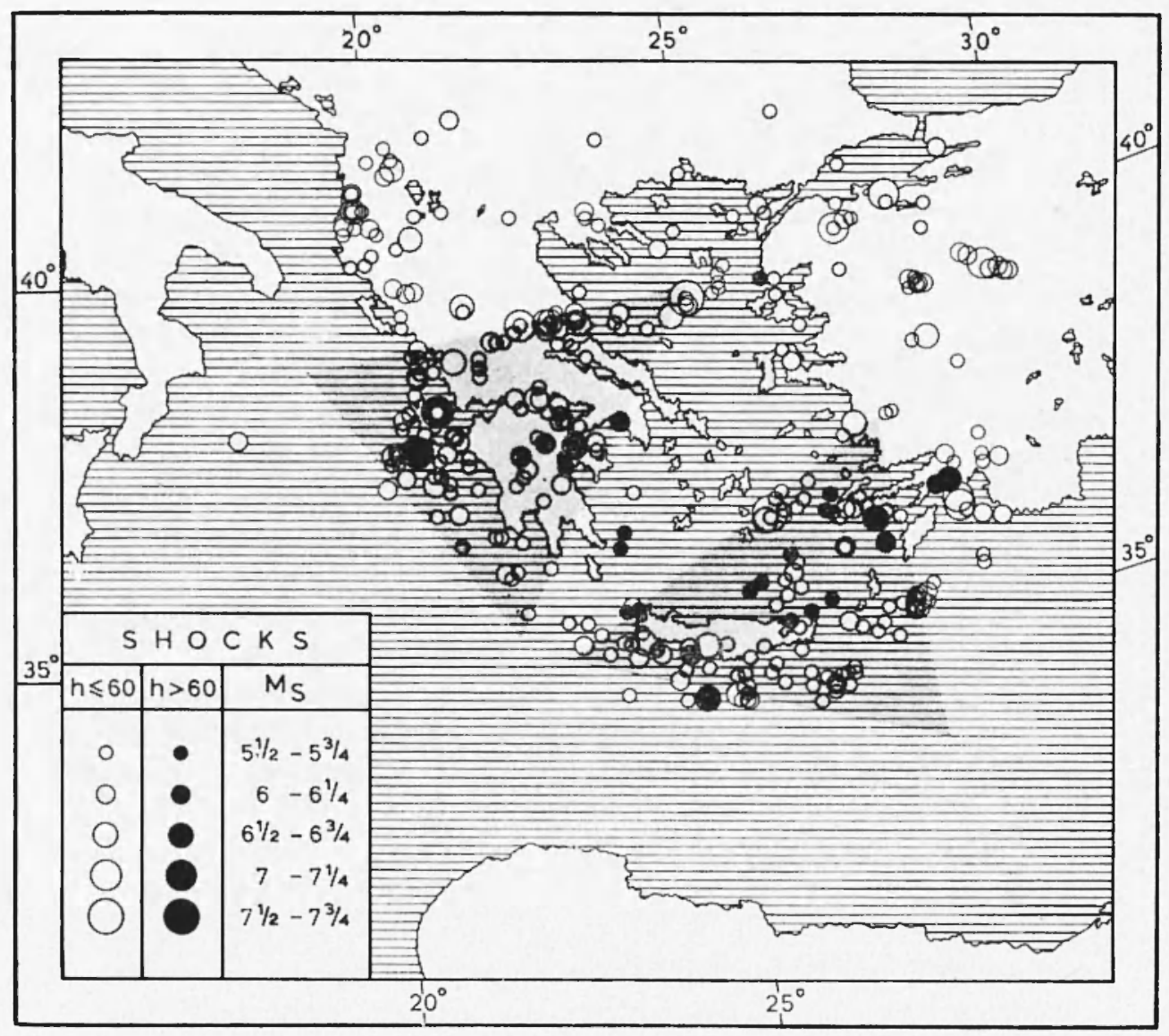

Fig. 5 - The active seismic trend of Greece, 1950-1973.

nogative Bouguer anomalies (6). It is believed that due to the high secliment supply rate of a number of rivers (for example Acheloos, Peneios, Alpheios) that flow to the Ionian Sea, a plate accretion must occur in the area. In Pacific island ares there is some evidence that aceretion of crustal material occurs on the island side of the trench. 
According to Lomnitz $\left({ }^{17}\right)$, the mechanisms of accretion and subruction are far from clear - cut; "accretion" as a mechanism of interaction between two plates does not necessarily involve an increase in the surface area of either plate, "since the growth can occur" as a vertical thickening rather than horizontal extension of the lithosphere".

Plate consumption at the northwestern margin of the Aegean subplate, if any, is rather low. The notion is strongly supporter by the lack of agreement between gravity distribution and orography; according to $\mathrm{H}$. Wunderlich ( $\left.{ }^{26}\right)$, this lack can be explainer only in terms of a shifting of orogenic activity, especially of orogenic foredeeps. Wunlerlich (26) believes that shifting of negative gravity anomalies is most prominent where orogenic activity continues most strongly at the present time. On the gromnls of this reasoning, the Minoides, i.e. the Peloponnese-Crete island are is the youngest among the various Mediterranean mountain chains and the only one still molergoing orogeny. In terms of plate tectonics, the Minoides is a double-are structure with a lange of folded mountains lying between the trench and the volcanoes $\left({ }^{19}\right)$.

Some years ago it was postulated that the large fault zone that surrounds the western and southern coasts of Greece marks the trend of a marginal geosyncline, which is now in the course of development in the eastern Mediterranean $\left(^{5}\right)$. It might be arded that even in the framework of the now widely accepted concept of plate tectonics the Hellenic Trough and the Mediterranean Rirlge may well be a typical pair of eugeosynclinal and miogreosynclinal structures in a "status nascenti" or embryonic stage. The trend of the Mediterranean Rirlge is very poorly portrayed in the distribution pattern of earthquake epicenter's; in general, the seismic activity along the Mediterranean Rirlge is sparse and by far less than that occurring along the Hellenic Trough. The fact that no clear inclications for horizontal compression were observed in the surveyer area of the Ionian Sea ${ }^{13}$ ) is not strange for a geosynclinal complet in process of formation $\left({ }^{4}\right)$. However, the question is still moot.

The second center of higher earthquake activity at the southeastern margin of the Aegean microplate (Dorlecanese-Crete) is a place of particularly high and wather continuous, intermediate focal depth seismic activity associater with a large zone of high positive gravity anomalies $\left(^{8}\right)$. The lack of any river of some importance indicates that the serliment supply rate in the area is relatively very low; consequently, no plate accretion is expected to occur there. The existence, on 
the other hand, of two very deep, subparallel trenches with little fill routheast of Crete (Pling trench, Strabo trench) combined with a very high subcrustal activity in the area considered, suggest that the subduction mates must be there relatively high (11).

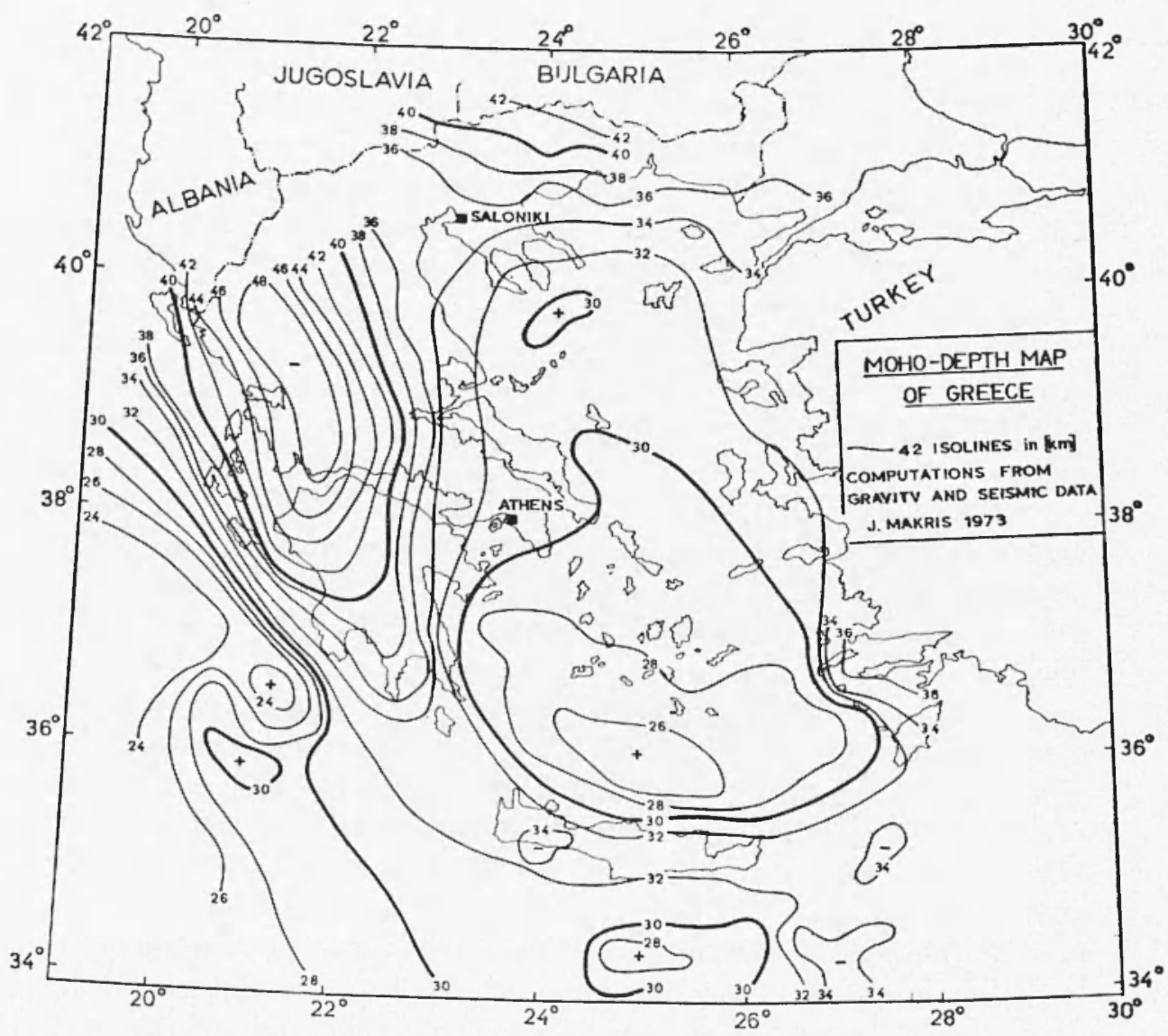

Fig. 6 - Depth contours of the Moho-diseontinuity in the area of Greece, aftor .J. Makris (1973).

Another point worth noting is that the large shock epicenters along the western segment of the Hellenic are tend to ocrur near the outer or seaward side of tho arc; in the southern segment there is a tendency of large shock epicenters to occur, as in most destructive plate 
boundaries (14), near the inner or islandward side of the are. Plots of the large shock epicenters ( $M \geqslant 7$ ) along the Hellenic alre an be foumd in Figures 5 and 6 of a previous work of the author (i).

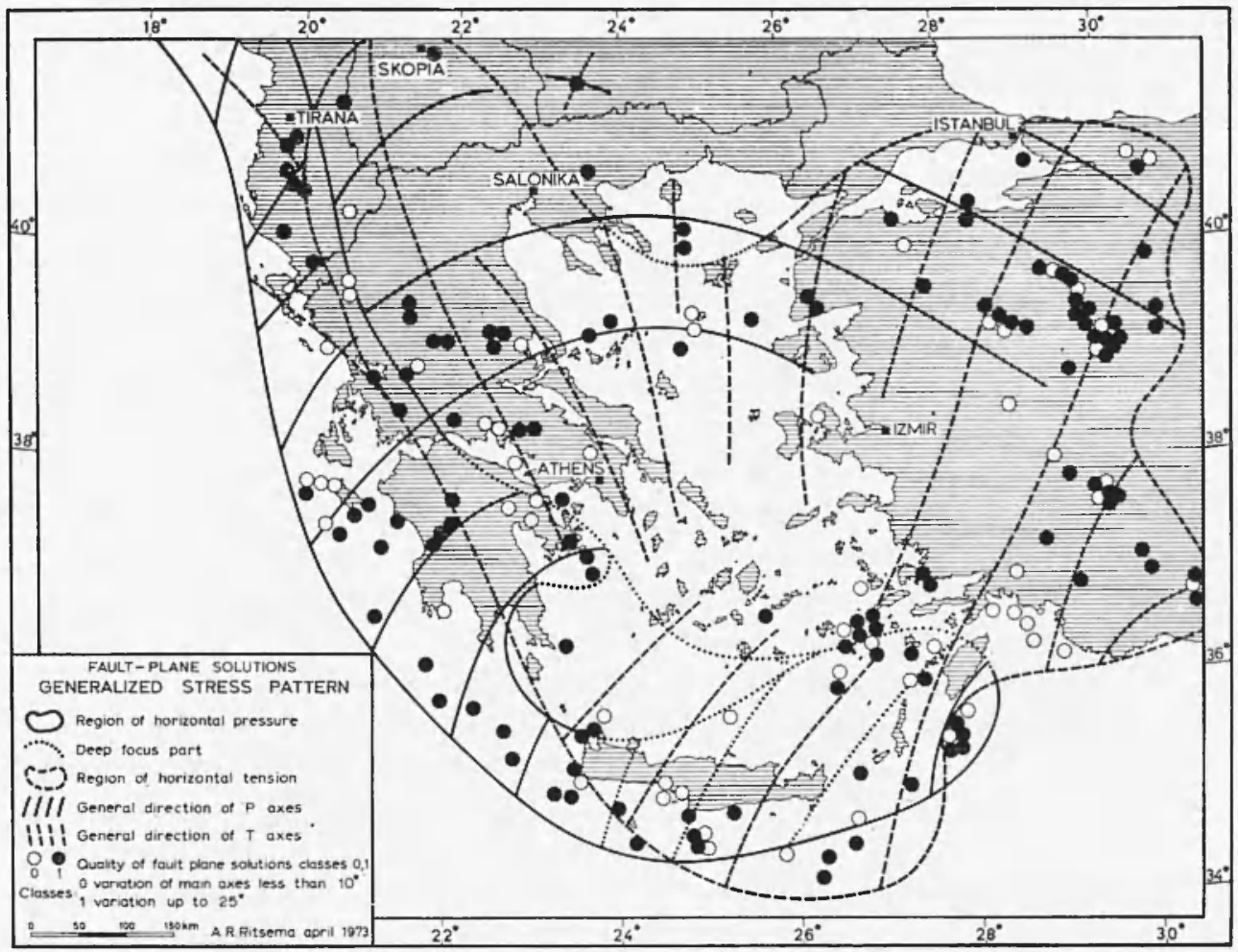

Fig. 7 - The general direction of the compressional and tensional stress in the area of Greece, after A. R. Ritsema (197t).

DISCUSSION AND REMARKS

On the grounds of the above considerations one might he allowed to conchule that the origin of the stress field in the northwestern center, at the constructive margin of the Aegean subplate, is rather shallow and in the southeastern center, at the destructive margin of the $\Delta f$ iadan plate, is surely moler the crust $\left({ }^{10}\right)$.

Th the area occupied by the second center of higher earthquale activity the relief of the Moho-rliscontinuity is shallower and smoother 
in comparison to that derived from gravity and seismic data for the area of the northwestern center $\left({ }^{18}\right)$. Further, the thickening of the Earth's crust along the Tonian zone (Fig. 6) may be interpreted as Evirlence that accretion has occurred there until recently or may still be occurring locally.

Another diflerence derived from the fault-plane solutions ( $\left.{ }^{25}\right)$ is that the Ionian center is seated in a region of predominant horizontal pressure; the second center in the southeastern legean Sea belongs to a region of paramount horizontal tension (Fig. $i$ ).

Observations by geologists who have had extensive field experience in the area of Greece have shown that since Pliocene the tectonics in the Cephalonia Island is compressional $\left({ }^{20}\right)$, and since the MindelRiss period tensional forces are predominant in the area of the Legean Sea (21). On the grounds of these and other features of the Aegean Sea, as for instance the large positive free-air gravity anomalies, the linear magnetic anomalies and the relatively thin crust, Boccaletti and associates $\left({ }^{2}\right)$ believe the Degean Sea, particularly the Cyclades area to be an extensional back-arc basin, i.e. a marginal sea in an early development stage formed by extension and accetion due to rising magma from the mantle.

However, by and large the compressional stress field seems to be continuous throughout the region of Greece and the general northeastsouthwest direction of the compressional stresses seems to be independent of the trend of the local arc structure and to be determined only by the relative motion direction of the African plate and the Anatolian or Turkish subplate. The result of these conflicting regimes is the formation of the Aegean basin by uplift and crashing of the intermediate crystalline mass and then collapsing under tension; according to $\mathrm{A}$. R. Ritsema $\left({ }^{25}\right)$, the tensional stresses alway's seem more or less directed towards the centre of this area.

Summing $u_{1}$, the Dodecanese-Crete-Center at the sonthern side of the Hellenic are is a subduction zone associated with tension, while the Tonian center at the western sicle is largely a zone of aceretion related to compression; this seems to be in contradiction with the general norm of predominant stresses across ronvergence zones of lithospheric plates.

Assuming a $\mathrm{X} 30^{\circ} \mathrm{E}$ direction of the slip vector $\left({ }^{10}\right)$ and a combined speed of about $10 \mathrm{~cm} /$ year between the African plate and the Aegean microplate $\left({ }^{15}\right)$, the difference in the tectonic processes along the Hellenic are might be attributed, after Xavier Le Pichon (16), 
to the greater speed of the two plates in the N-S direction (about S.T, i.e. more than $6 \mathrm{~cm} /$ year) in comparison to that in the E-W direction (about 5, i.e. less than $6 \mathrm{~cm} /$ year $^{2}$ ).

\section{REFERENCES}

(1) Aubotix J., 1965. - Geosynclines. "Amsterdam Elsevier Publ. Co.", p. 335 .

(2) Boccalett M., Maxetti P. and Peccernido A., 197t. - The Balkanids as an Instance of Back-ire Thrust Bell: Possible Relation with the Hellenids. "Greol. Soc. America Bull.", 85, plp. 1077-1084.

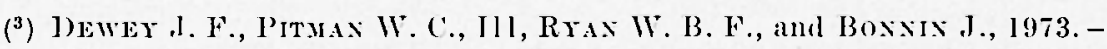
Plate Tedonies and the Evolution of the Alpine System. "Geol. Soc. Anerica Bull.", 84, pp. 3137-3180.

(1) DIET\% R., 1972. - Geosynolines, Mountains, and Comtinent-Building, "Continents Adrift" (Readings from "Scientific Aneriean" compiled by J. Tuzo Wilson), W. II. Freeman and Co., San Francisco, 13, pl). $124-132$.

(5) Galaxopoulos A. G., 1963. - On Mapping of Seismic Aclivily in (ireece. "Annali di fieofisica", XVI, 1, pp. 37-100.

(6) Galanopoudos A. (1., 1965. - The large Conjugale Faull system and the Associaled Earlhquale Adivily in Greece. "Ann. Gielol. d. Pays Hellén.", 18, pl). 119-134.

(7) Galaxopoudos A. G., 1967. - The Seismolectomic Regime in Greece. "Annali di Geofisiea", XX, 1, 1). 109-119.

(8) Gataxopoulos A. G., 1968. - The earthqualie Activity in the Physiographic Provinces of the Eastern Mediterramean Sea. "Ann. Geol. dl. Pays Hellin.", 21, pl. 178-209.

(9) Gatanopoulos A. G., 1971. - Space-time Seismicily of Greece. "Proc. Acal. Athens". 46. pl. 216-224.

(10) Gataxopoulos A. G., 1973. - Plate Tectonies in the Area of Greece as Reflected in the Deep Focus seismicily. "Annali di Creofisica", XXVI, 1, pl. 85-105.

(11) Galaxopoudos A. G., 1973. - On the Difierence of the stress Field in the Two Centers of Higher Earlhquake Letivity in the Area of Greece. "snm. Géol. 1. Pays Ilellén.", 25, pp. 350-372.

(12) (ivoratanes N. A., 1973. - Mylhology and Geology (in Greeh). Athens, pl. $1-16$.

(13) Hixz K., 1974. - Resulls of Seismic Refraction and Seismic Reflection. Measurements in the Ionian sea. "Greol. Jh.", E2, pp. 33.65. 
(1.1) Kat.rener J., Sykes L,, and Ohyer I., 1973. - Possible Criteria for Predicting Earthquale Locations and Their Application Io Major Plate Boundaries of the Pacific and the Caribean. "Jour. Geoph. Res.", 78, 14, pl). $2547-2585$.

(15) Koya.exsкy .J., 1973. - La Géodésie śpaliale. "Laa Recherche", 4, 33 , pp. $339-346$.

${ }^{\left({ }^{16}\right)}$ Le Pichox X., Franchetrau J., and Boxwix J., 1973. - Plale Teclonics. "Elsevier sici. Publ. Co", p. 300.

(ii) Losxiт\% C., 1974. - Global Tectonics and Earlhqualie Risk. Developments in Geotectomics, 5. "Elserier Sei. Publ. Co." (Amsterdam - Lomdon S(w York), p. 320.

(14) MakRIs J., 1973. - Some Geophysical Aspects of the Evolution of the IIctlenides. "Bull. Geol. Soe of Greece", 10, pp. 206-213.

(19) Mrxard II. W., 1969. - The Deep-Ocean Floor. "Continents Mdrife" (Roarlings from "sicientife American" compilen by J. Tuzo Wilson), W. II. Freeman and (o., San Franciseo, 1972. pl). $79-87$.

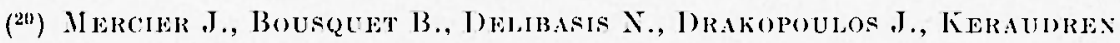
B., and LEMEILte F., 1972. - Les deformations en Compression dans le Qualermaire des rinages Ioniens (C'éphalonie, Girèce), Données néolectoniques el séismiques. "C. R. Sciences", Paris, 275, pp. 2307-2310.

(21) Mrecier J., Botsquet B., Medibasis T., Drakopoulos J., Keraudrex

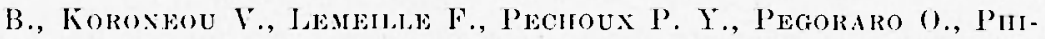
LiP II., SAUVAGE J., and Soret 1)., 1973. - Déformations superficielles en compression el en erlension dans la "Plaque égéenne" (Grèce) au cours du Pliocène el du Quaternaire. "Rémion Amuelle des se. de la Teree", Paris, 19-22 Mars, p. 297.

${ }^{(22)}$ ICKexzie D. P., 1970. - Plale Teclonies of the Medilerranean Region. "Nature", 226, [1. 239-243.

${ }^{(23)}$ Nicmots I. A., 1971. - Pelrology of Sambrimi Coleani, Cyclades, Greece. "Jour. Petrology", 12, pp. (67-121.

(24) Niscovicn D. and II ays D. J., 1972. - Medilerranean Island tres and Origin of Migh Polash Toleanoes. "Farth and Planetary seience Letlers", 16, P!. 331-345.

$\left.{ }^{(25}\right)$ RrTsema A. R., 1974. - The Earlhquake Mechanisms of the Balkan Region. "Royal Neth. Met. Inst ", De Bilt, Scientific Report Nr. 74-4, p. 36.

(26) Wuxiderucir G. II., 1971. - Gravily Anomalies, shifling Foredeeps, and the Role of Gravity in Nappe Transport as Shown by the Minsides (Eastern lledilerranean). Van Bommelen: Volume, "Gravity and Teetonies", Lditors: Kees A. De Jong and Robert Scholten, John Wiley and Sons, Now lork, pp. $271-285$. 